J-SISKO TECH

Jurnal Teknologi Sistem Informasi dan Sistem Komputer TGD

$P: I S S N$ : 2621-8976 E-ISSN : 2615-5133

Vol.3, No.1, Januari 2020, pp.60-69

\title{
Sistem Pendukung Keputusan Penentuan Koperasi Terbaik Di Kota Pekanbaru Menggunakan Metode Electre (Ellimination And Choice Translation Reality) Studi Kasus : Dinas Koperasi Ukm Kota Pekanbaru
}

\author{
Imam Rangga Bakti \\ Program Studi Sistem Informasi, Universitas Tjut Nyak Dhien \\ Jl. Sei Sikambing, Medan Helvetia, Indonesia, 20122 \\ E-mail: imamranggabakti@gmail.com
}

\begin{abstract}
Abstrak
Dinas Koperasi UKM Kota Pekanbaru merupakan lembaga yang bertanggung jawab penuh terhadap seluruh koperasi yang ada di Kota Pekanbaru. Salah satu program kerja Dinas Koperasi UKM Kota Pekanbaru adalah memberikan reward kepada koperasi terbaik yang ada di Kota Pekanbaru. Dalam melakukan proses seleksi penentuan koperasi terbaik, Dinas Koperasi UKM Kota Pekanbaru mengalami kesulitan dalam menentukan koperasi mana yang terbaik dengan tepat karena setiap koperasi memiliki nilai kriteria dan aspek aspek yang hampir sama untuk penilaian koperasi terbaik. Dalam membantu dan mempermudah penilai dalam melakukan seleksi penetuan koperasi terbaik dengan mudah, dapat menggunakan Metode Electre sebagai Sistem Pendukung Keputusan. data yang di olah pada penelitian ini terdapat 47 kriteria yang didapatkan dari pegawai Dinas Koperasi UKM Kota Pekanbaru. Adapun tahapan metode Electre dapat melakukan perhitungan membentuk tabel normalisasi, penentuan matrik $\mathrm{V}$, perbandingan berpasangan Concordance dan Discordance dan perangkingan hasil akhir. Sistem ini dibangun menggunakan bahasa pemograman PHP dan database MySQL. Hasil dari penelitian ini menghasilkan nilai rekomendasi yang valid dan tepat untuk penentuan koperasi terbaik. Dari hasil pembuatan aplikasi ini dapat memberikan kemudahan terhadap pihak penilai pada Dinas Koperasi UKM Kota Pekanbaru dalam melakukan penentuan koperasi terbaik.
\end{abstract}

Kata Kunci: SPK, Electre, Aplikasi, php, MySql

\begin{abstract}
Pekanbaru City Cooperative Office is an institution that is fully responsible for all cooperatives in the city of Pekanbaru. One of the work programs of the Pekanbaru City Cooperative Office is to give rewards to the best cooperatives in the city of Pekanbaru. In conducting the selection process for determining the best cooperatives, the Pekanbaru City Cooperative Service Office has difficulty in determining which cooperatives are best because each cooperative has almost the same criteria and aspects for the assessment of the best cooperatives. In assisting and facilitating assessors in selecting the best cooperative decisions easily, can use the Electre Method as a Decision Support System. The data processed in this study contained 47 criteria obtained from employees of the Pekanbaru City Cooperative Office. The stages of the Electre method can perform calculations forming normalization tables, determination of matrix $\mathrm{V}$, pairing comparisons of Concordance and Discordance and ranking of final results. This system was built using the PHP programming language and MySQL database. The results of this study produce valid and appropriate recommendation values for determining the best cooperative.
\end{abstract}


From the results of making this application can provide convenience to the assessors at the Pekanbaru City Cooperative Office of SMEs in determining the best cooperative.

Keywords: SPK, Electre, Application, php, MySql

\section{PENDAHULUAN}

Pada Kota Pekanbaru ada terdapat Koperasi yang berada di bawah Dinas Koperasi dan UKM kota Pekanbaru. Dinas Koperasi memiliki peranan, fungsi serta tugas pokok, salah satunya tentang hal kemajuan dan pembinaan dari Koperasi yang berada di bawah dinas Koperasi dan UKM tersebut. Dinas Koperasi dan UKM juga melakukan penilaian terhadap Koperasi, dan nantinya akan akan di lakukan pemilihan Koperasi terbaik, yang mana akan berguna untuk meningkatkan kinerja dan potensi dari Koperasi tersebut. Jika ada dana bantuan dari pusat maupun propinsi ataupun dana lainnya yang diperuntukkan untuk Koperasi yang ada di Kota Pekanbaru, maka bantuan dana tersebut di utamakan untuk Koperasi dengan kinerja yang terbaik.

Selama ini dinas Koperasi dan UKM Kota Pekanbaru melakukan penilaian terhadap setiap Koperasi yang ada secara manual, yaitu setiap data data informasi Koperasi yang kriteria penilaiaannya meliputi tata lakasana,produktivitas, manajemen, organisasi, manfaat dan dampak dan pengembangan daya saing, dikumpulkan oleh penilai dari dinas Koperasi. Selanjutnya data tersebut akan dihitung secara manual. Secara manual yang dimaksud yaitu data masukan diberikan penilaian dari setiap kriteria dan sub kriteria yang ada, dengan menggunakan kertas kerja penilaian Koperasi terbaik kemudian di hitung dengan mempergunakan Microsoft Exel dan nilai tertinggi merupakan yang terbaik.

Dalam hal penilaian, hasil yang didapat menjadi tidak maksimal, dikarenakan ada kriteria yang bersifat subyektif. Tentu hal ini akan menyulitkan, disamping keputusan yang tidak akurat dan membutuhkan proses yang lama dalam hal penyeleksian Koperasi yang berada di bawah Dinas Koperasi UKM Kota Pekanbaru. Dari kondisi di atas, maka diperlukan sistem yang terkomputerisasi yang akan mengolah data dari alternatif setiap keputusan. Dari hasil pengolahan data informasi yang ada dengan mempergunakan model pendukung keputusan dengan tujuan data di peroleh lebih cepat dan akurat serta dapat menigkatkan efisiensi waktu dan juga biay.

\section{METODE PENELITIAN}

1. Sistem Pendukung Keputusan

SPK adalah sistem informasi berdasar komputer yang interaktif, fleksibel dan dapat beradaptasi, secara khusus dikembangkan untuk mendukung suatu solusi dari pengelolaan yang tidak terstruktur untuk meningkatkan pembuatan keputusan, memanfaatkan data, membutuhkan antarmuka dengan pemakai yang mudah, dan mengijinkan si pembuat keputusan mempunyai wawasan sendiri (Kaswidjanti, dkk dalam Turban, dkk 2015).

\section{ELECTRE (Elimination Et Choix Traduisant La Realite)}

Electre merupakan salah satu metode pengambilan keputusan multikriteria berdasarkan pada konsep Outranking dengan menggunakan perbandingan berpasangan dari alternatifalternatif berdasarkan setiap kriteria yang sesuai. Metode Electre digunakan pada kondisi dimana alternatif yang kurang sesuai dengan kriteria dieliminasi, dan alternatif yang sesuai dapat dihasilkan.(Janko dan Bernoider dalam Setiawan, dkk 2015)

\section{ANALISIS DAN HASIL}

Berdasarkan penjelasan tentang metode ELECTRE setelah itu diterjemahkan kedalam bentuk diagram alir (Flowchart) yang kemudian implementasi dan pengujian. Diagram alir metode ELECTRE dapat dilihat dalam bentuk gambar.1 di bawah ini. 


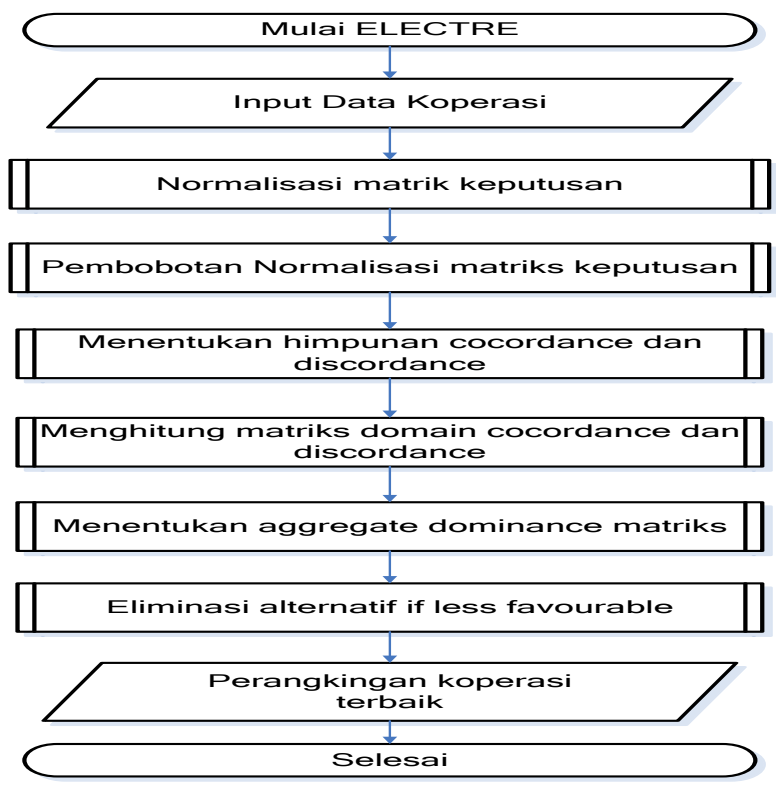

Gambar.1 Flowchart langkah-langkah metode ELECTRE (ELIMINATION ET CHOIX TRADUISANT LA REALITÉ)

\section{Input Data Koperasi}

Tabel .1 Data Alternatif

\begin{tabular}{|c|l|}
\hline No & \multicolumn{1}{|c|}{ Nama Koperasi } \\
\hline 1 & ASA TUAH ANAK NEGERI \\
\hline 2 & CAHAYA \\
\hline 3 & CAHAYA PLN \\
\hline 4 & FORMASI TUJUH \\
\hline 5 & HUTAMA KARYA \\
\hline 6 & KONDANG SEMARI \\
\hline 7 & KOPAKLI \\
\hline 8 & KOPANUSA \\
\hline 9 & KOPPAS 50 \\
\hline 10 & P 4 D \\
\hline
\end{tabular}

2. Normalisasi Matriks Keputusan

Dari perhitungan diatas diperoleh matriks sebagai berikut :

$$
\begin{aligned}
R_{11}=\frac{X_{11}}{\sqrt{\sum_{i=1}^{m} X_{i 1}^{2}}} & =\frac{0.5}{\sqrt{0.5^{2}+2^{2}+1.5^{2}+1.5^{2}+1.5^{2}+2^{2}+1.5^{2}+2^{2}+1.5^{2}+1.5^{2}}} \\
& =\frac{0.5}{5.074446}=0.098533
\end{aligned}
$$

J-SISKO TECH Vol. 3, No. 1, 2020 : 60-69 


$$
\begin{aligned}
& R_{12}=\frac{X_{12}}{\sqrt{\sum_{i=1}^{m} X_{i 1}^{2}}}=\frac{2}{\sqrt{0.5^{2}+2^{2}+1.5^{2}+1.5^{2}+1.5^{2}+2^{2}+1.5^{2}+2^{2}+1.5^{2}+1.5^{2}}}=\frac{2}{5.074446} \\
& =0.394132 \\
& R_{1 \mathrm{a}}=\frac{X_{1 \mathrm{a}}}{\sqrt{\sum_{\mathrm{i}=1}^{m} X_{\mathrm{i}}^{2}}}=\frac{1.5}{\sqrt{0.5^{2}+2^{2}+1.5^{2}+1.5^{2}+1.5^{2}+2^{2}+1.5^{2}+2^{2}+1.5^{2}+1.5^{2}}}=\frac{1.5}{5.074446} \\
& =0.295599 \\
& R_{14}=\frac{X_{14}}{\sqrt{\sum_{i=1}^{m} X_{i 1}^{2}}}=\frac{1.5}{\sqrt{0.5^{2}+2^{2}+1.5^{2}+1.5^{2}+1.5^{2}+2^{2}+1.5^{2}+2^{2}+1.5^{2}+1.5^{2}}}=\frac{1.5}{5.074446} \\
& =0.295599 \\
& R_{15}=\frac{X_{15}}{\sqrt{\sum_{i=1}^{m} X_{i 1}^{2}}}=\frac{1.5}{\sqrt{0.5^{2}+2^{2}+1.5^{2}+1.5^{2}+1.5^{2}+2^{2}+1.5^{2}+2^{2}+1.5^{2}+1.5^{2}}}=\frac{1.5}{5.074446} \\
& =0.295599 \\
& R_{16}=\frac{X_{16}}{\sqrt{\sum_{i=1}^{m} X_{i 1}^{2}}}=\frac{2}{\sqrt{0.5^{2}+2^{2}+1.5^{2}+1.5^{2}+1.5^{2}+2^{2}+1.5^{2}+2^{2}+1.5^{2}+1.5^{2}}}=\frac{2}{5.074446} \\
& =0.394132 \\
& R_{17}=\frac{X_{17}}{\sqrt{\sum_{i=1}^{m} X_{i 1}^{2}}}=\frac{1.5}{\sqrt{0.5^{2}+2^{2}+1.5^{2}+1.5^{2}+1.5^{2}+2^{2}+1.5^{2}+2^{2}+1.5^{2}+1.5^{2}}}=\frac{1.5}{5.074446} \\
& =0.295599 \\
& R_{18}=\frac{X_{18}}{\sqrt{\sum_{i=1}^{m} X_{i 1}^{2}}}=\frac{2}{\sqrt{0.5^{2}+2^{2}+1.5^{2}+1.5^{2}+1.5^{2}+2^{2}+1.5^{2}+2^{2}+1.5^{2}+1.5^{2}}}=\frac{2}{5.074446} \\
& =0.394132 \\
& \mathrm{R}_{19}=\frac{X_{19}}{\sqrt{\sum_{i=1}^{m} X_{i 1}^{2}}}=\frac{1.5}{\sqrt{0.5^{2}+2^{2}+1.5^{2}+1.5^{2}+1.5^{2}+2^{2}+1.5^{2}+2^{2}+1.5^{2}+1.5^{2}}}=\frac{1.5}{5.074446} \\
& =0.295599 \\
& \mathrm{R}_{20}=\frac{X_{20}}{\sqrt{\sum_{i=1}^{m} X_{i 1}^{2}}}=\frac{1.5}{\sqrt{0.5^{2}+2^{2}+1.5^{2}+1.5^{2}+1.5^{2}+2^{2}+1.5^{2}+2^{2}+1.5^{2}+1.5^{2}}}=\frac{1.5}{5.074446} \\
& =0.295599
\end{aligned}
$$

dengan cara yang sama dalam membentuk matrik keputusan setiap alternatif ditiap kriteria pada K01 dapat diperoleh (r11, r12,..r110), K02 (r21, r22,..r210), K04 (r31, r32,..r130), K05 dan seterusnya, proses penghitungan dari perhitungan di atas diperoleh matriks $\mathrm{R}$ sebagai berikut:

$R=\left[\begin{array}{cccccc}0.098533 & 0.102062 & 0.00000 & 0.101015 & 0.169031 & 0.12500 \\ 0.394132 & 0.408248 & 0.304997 & 0.404061 & 0.338062 & 0.37500 \\ 0.295599 & 0.408248 & 0.304997 & 0.202031 & 0.507093 & 0.37500 \\ 0.295599 & 0.306186 & 0.457496 & 0.404061 & 0.169031 & 0.12500 \\ 0.295599 & 0.306186 & 0.304997 & 0.404061 & 0.169031 & 0.25000 \\ 0.394132 & 0.306186 & 0.304997 & 0.303046 & 0.169031 & 0.37500 \\ 0.295599 & 0.306186 & 0.152499 & 0.303046 & 0.338062 & 0.37500 \\ 0.394132 & 0.306186 & 0.304997 & 0.303046 & 0.338062 & 0.37500 \\ 0.295599 & 0.306186 & 0.457496 & 0.303046 & 0.169031 & 0.37500 \\ 0.295599 & 0.306186 & 0.304997 & 0.303046 & 0.507093 & 0.25000\end{array}\right]$

\section{Pembobotan Pada Matriks Yang Telah Dinormalisasi}

$V 12=R 11 \times W 1=0.98533 \times 0.5=0.197066$

$\mathrm{V} 21=\mathrm{R} 12 \times \mathrm{W} 1=0.394132 \times 0.5=0.788264$ 


$$
\begin{aligned}
& V 31=\mathrm{R} 13 \times W 1=0.295599 \times 0.5=0.591198 \\
& V 41=\mathrm{R} 14 \times W 1=0.295599 \times 0.5=0.591198 \\
& V 51=\mathrm{R} 15 \times W 1=0.295599 \times 0.5=0.591198 \\
& V 61=\mathrm{R} 16 \times W 1=0.394132 \times 0.5=0.788264 \\
& V 71=\mathrm{R} 17 \times W 1=0.295599 \times 0.5=0.591198 \\
& V 81=\mathrm{R} 18 \times W 1=0.394132 \times 0.5=0.788264 \\
& V 91=\mathrm{R} 19 \times \mathrm{W} 1=0.295599 \times 0.5=0.591198 \\
& V 101=\mathrm{R} 20 \times \mathrm{W} 1=0.295599 \times 0.5=0.591198
\end{aligned}
$$

Dengan cara yang sama dalam menghitung faktor kepentingan (bobot) pada setiap kriteria dapat diperoleh $(\mathrm{V} 12, \mathrm{~V} 22, \ldots . \mathrm{V} 102),(\mathrm{V} 13, \mathrm{~V} 33, \ldots . \mathrm{V} 103)$, dan seterusnya, proses penghitungan dari perhitungan diatas diperoleh matriks $\mathrm{V}$ sebagai berikut :

$V=\left[\begin{array}{llllll}0.19707 & 0.20412 & 0.00000 & 0.20203 & 0.50709 & 0.12500 \\ 0.78826 & 0.81650 & 0.91499 & 0.80812 & 1.01419 & 0.37500 \\ 0.59120 & 0.81650 & 0.91499 & 0.40406 & 1.52128 & 0.37500 \\ 0.59120 & 0.61237 & 1.37249 & 0.80812 & 0.50709 & 0.12500 \\ 0.59120 & 0.61237 & 0.91499 & 0.80812 & 0.50709 & 0.25000 \\ 0.78826 & 0.61237 & 0.91499 & 0.60609 & 0.50709 & 0.37500 \\ 0.59120 & 0.61237 & 0.45750 & 0.60609 & 1.01419 & 0.37500 \\ 0.78826 & 0.61237 & 0.91499 & 0.60609 & 1.01419 & 0.37500 \\ 0.59120 & 0.61237 & 1.37249 & 0.60609 & 0.50709 & 0.37500 \\ 0.59120 & 0.61237 & 0.91499 & 0.60609 & 1.52128 & 0.25000\end{array}\right]$

4. Menentukan Himpunan Concordance dan Discordance pada Index

a. Concordance

Sebuah kriteria dalam suatu alternatif termasuk concordance jika:

$$
C_{12}=\left\{j, v_{1} \geq v_{2 j}\right\}=\operatorname{untuk} j=1,2, \ldots \ldots \ldots n
$$

Hasil concordance yang didapat, yaitu:

$$
\begin{aligned}
& C_{12}=\{2,2,1,2,3,3,2,2,3,2,3,2,2,2,1,1,1,2,2,1,2,2,2\} \\
& C_{19}=\{2,2,1,3,3,2,3,2,2,3,2,3,2,2,2,2,3,2,1,1,2,1,2,2,2\} \\
& C_{14}=\{3,1,2,1,1,3,3,3,2,2,3,2,2,2,2,1,2,2,1,2\} \\
& C_{15}=\{3,2,2,2,1,2,3,3,2,2,3,2,3,2,2,1,1,3,2,1,2,2,\} \\
& C_{16}=\{3,2,2,1,1,2,3,3,2,3,2,2,3,2,2,1,2,2,1,2,2\} \\
& C_{17}=\{2,2,2,2,1,2,3,3,2,3,3,2,3,2,2,2,2,2,2,1,1,2\} \\
& C_{19}=\{2,2,2,1,1,3,3,2,3,2,2,3,3,2,2,2,1,1,3,1,2\} \\
& C_{19}=\{3,2,2,2,2,2,1,1,2,3,3,2,3,2,3,2,2,2,2,2,2,2,1,3,2,1,2,2\} \\
& C_{20}=\{2,2,2,1,3,3,2,5,2,3,3,2,2,3,2,3,2,2,2,2,1,1,2,1,2,2,2\}
\end{aligned}
$$

\section{b. Discordance}

Sebuah kriteria dalam suatu alternatif termasuk discordance jika:

$D_{12}=\left\{j, v_{1} \leq v_{2 j}\right\}=$ untuk $j=1,2, \ldots \ldots \ldots n$

Hasil discordance yang didapat, yaitu:

$$
\begin{aligned}
& D_{12}=\{2,2,3,2,3,1,2,2,2,2,1,2,3,5,2,2,3,3,2,2,2,2,3,2,2,2,2,3,2,2,1,1,1,3,2,2,1,2,2,2,2,2\} \\
& D_{12}=\{2,2,3,2,3,1,2,2,2,2,1,2,3,5,2,2,3,2,2,2,2,2,3,2,1,3,2,2,1,2,2,2,2\} \\
& D_{14}=\{2,2,3,2,3,1,2,2,2,2,1,2,3,2,5,2,2,3,3,2,2,2,3,2,2,2,23,2,2,1,1,3,2,2,1,2,2,2,2\} \\
& D_{15}=\{2,2,3,2,3,1,2,2,2,2,1,1,2,3,5,2,2,3,3,2,2,2,3,2,2,2,2,3,2,2,1,1,2,2,1,2,2,2,2,2\}
\end{aligned}
$$

J-SISKO TECH Vol. 3, No. 1, 2020 : 60-69 


$$
\begin{aligned}
& D_{16}=\{2,2,3,2,3,1,2,2,2,2,2,1,1,2,5,2,2,3,3,2,2,3,2,2,2,3,2,2,1,1,3,2,2,1,2,2,2,2,2\} \\
& D_{17}=\{2,2,3,2,3,1,2,2,2,1,1,2,3,2,5,2,2,3,3,2,2,2,2,3,2,2,2,2,3,2,2,1,1,1,3,2,2,2,2,2,2,2,2\} \\
& D_{19}=\{2,2,3,2,3,1,2,2,2,2,1,1,2,2,5,2,2,3,3,2,2,2,3,2,3,2,2,2,3,2,1,1,1,3,2,2,1,2,2,2,2,2\} \\
& D_{19}=\{2,2,3,2,3,1,1,2,3,3,2,5,2,2,3,3,2,2,2,2,3,2,2,2,3,2,2,1,1,2,2,2,2,2,2\} \\
& D_{20}=\{2,2,3,2,3,1,2,2,2,2,1,2,2,5,2,2,3,2,2,2,2,3,2,2,23,2,1,1,1,3,2,2,1,2,2,2,2\}
\end{aligned}
$$

\section{Menghitung Matriks Concordance dan Discordance}

\section{a. Menghitung Matriks Concordance}

$$
\begin{gathered}
c_{k 1}=\sum_{j c_{w}} w_{j} \\
C_{12}=W 1+W 2+W 3+W 4+W 5+w 7+\cdots W n \\
=2+2+1+2+3+3+2+3+2+3+2+2+2+2+1+1+1+2+2+1+2+2 \\
+2=45
\end{gathered}
$$

Tabel .2 Data Matriks Concordance

\begin{tabular}{|l|c|c|c|c|c|c|c|c|c|c|}
\hline Nama & \multicolumn{8}{|c|}{ Data Nilai Matriks Concordance } \\
\hline ASA TUAH ANAK NEGERI & - & 45 & 52 & 40 & 46 & 43 & 46 & 43 & 58 & 59 \\
\hline CAHAYA & 89 & - & 80 & 79 & 84 & 82 & 81 & 66 & 77 & 84 \\
\hline CAHAYA PLN & 71 & 52 & - & 100 & 64 & 54 & 62 & 51 & 54 & 65 \\
\hline FORMASI TUJUH & 86 & 66 & 78 & - & 77 & 68 & 77 & 58 & 73 & 83 \\
\hline HUTAMA KARYA & 84 & 67 & 78 & 78 & - & 67 & 75 & 56 & 63 & 78 \\
\hline KONDANG SEMARI & 82 & 76 & 71 & 75 & 76 & - & 76 & 64 & 73 & 77 \\
\hline KOPAKLI & 89 & 60 & 75 & 76 & 90 & 62 & - & 61 & 81 & 75 \\
\hline KOPANUSA & 88 & 61 & 73 & 65 & 1 & 65 & 68 & - & 70 & 81 \\
\hline KOPPAS 50 & 77 & 60 & 73 & 90 & 67 & 65 & 70 & 53 & - & 70 \\
\hline P 4 D & 79 & 59 & 67 & 56 & 54 & 55 & 58 & 44 & 62 & - \\
\hline
\end{tabular}

b. Menghitung Matriks Discordance

$$
\begin{aligned}
& d_{k l}=\frac{\left\{\max \left(v_{m n}-v_{m n-1 n}\right) ; m_{s} n_{s} \varepsilon d_{k l}\right\}}{\left\{\max \left(v_{m n}-v_{m n-1 m}\right) ; m_{s} n_{s}=1,2,3, \ldots\right\}} \\
& \left\{\begin{array}{c}
\max (0.2-0.8) ;(0.2-0.8) ;(0-0.9) ;(0.2-0.8) ;(0.5-1) ;(0.1-0.4) ; \\
(0.4-0.7) ;(0.3-0.6) ;(0.3-0.6) ;(0.3-0.4) ;(0.6-2.4) ;(0.3-0.6) ; \\
(0.4-1.5) ;(0.3-0.6) ;(0.4-0.8) ;(0.4-0.7) ;(0.3-0.7) ;(0.5-0.8) ; \\
(0.5-0.8) ;(0.4-0.9) ;(0.4-0.7) ;(0.6-1.2) ;(0.3-1) ;(0.6-0.9)
\end{array}\right\} \\
& \left\{\begin{array}{c}
\max (0.2-0.8) ;(0.2-0.8) ;(0-0.9) ;(0.2-0.8) ;(0.5-1) ;(0.1-0.4) ; \\
(0.4-0.7) ;(0.3-0.6) ;(0.3-0.6) ;(0.6-0.6) ;(0.7-0.4) ;(0.4-0.2) \\
(0.3-0.4) ;(0.5-0.5) ;(1.6-0.8) ;(1.1-1.1) ;(0.7-0.3) ;(0.6-2.4) \\
(0.5-0.5) ;(0.3-0.6) ;(0.4-1.5) ;(1-1) ;(0.6-0.6) ; 0.3-0.6) ;(0.4-0.8) \\
;(1.7-0.8) ;(0.6-0.6)(0.4-0.7) ;(0.3-0.7) ;(0.5-0.5) ;(0.5-0.8) ; \\
(0.5-0.8) ;(0.4-0.9) ;(0.4-0.7) ;(0.6-0.6) ;(0.2-0.2) ;(0.3-0.3) ; \\
(0.3-0.3)(0.6-1.2) ;(0.3-0.3) ;(0.3-0.3) ;(0.3-0.3) ;(0.3-1) ; \\
(0.3-0.3) ;(0.6-0.9) ;(0.4-0.4) ;(0.3-0.3)
\end{array}\right\}
\end{aligned}
$$




$$
d_{12}=\frac{\{1.8\}}{\{1.8\}}
$$

$=1$

Tabel .3 Data Matriks Discordance

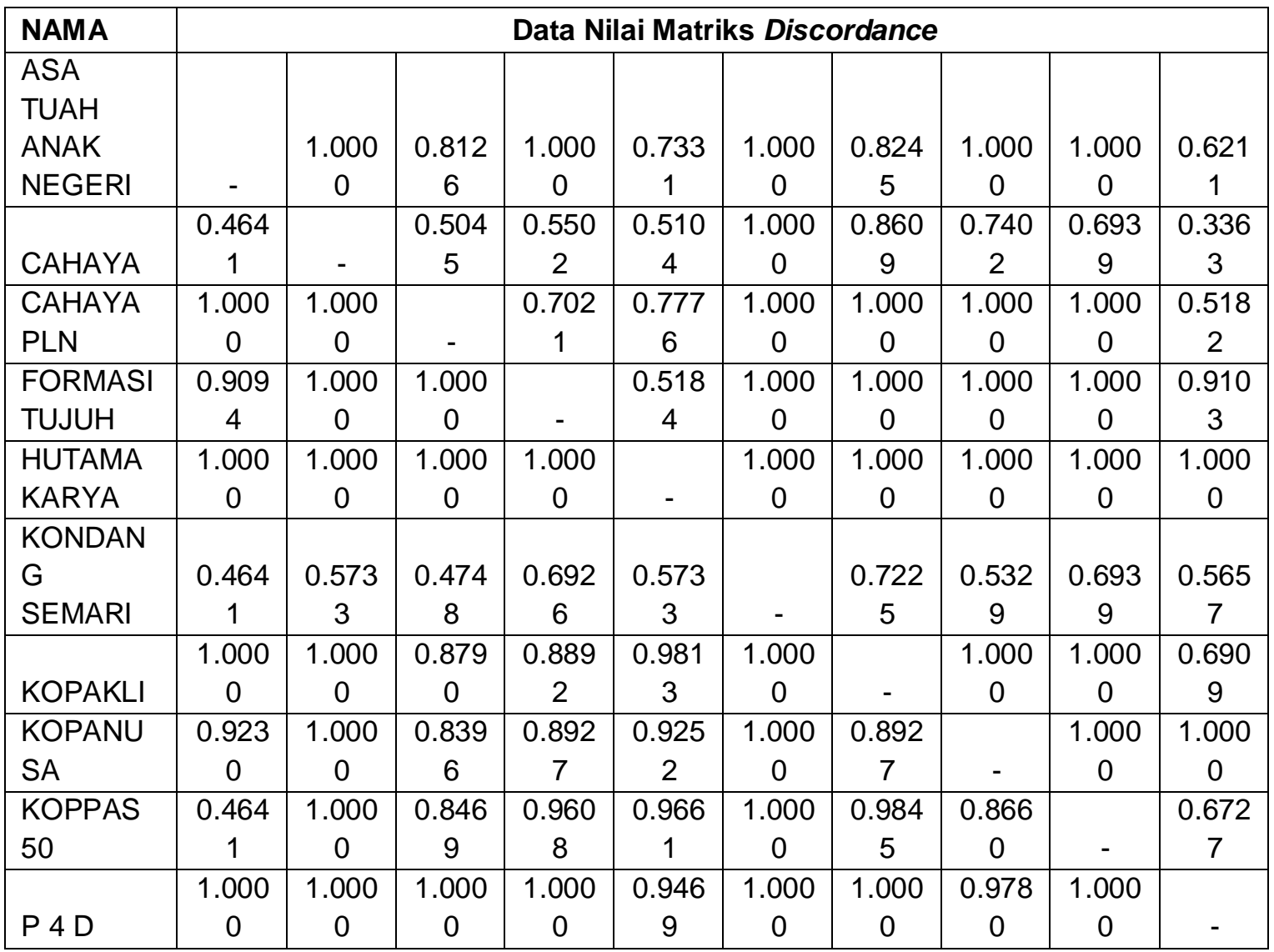

6. Menghitung Matriks Dominan Concordance dan Discordance a. Menghitung Matriks Dominan Concordance

Nilai threshold (c) adalah :

$$
c=\begin{gathered}
45+52+40+46+43+46+43+58+59+89+80+79+84+82+81 \\
66+77+84+71+52+100+64+54+62+51+54+65+86+66+78 \\
+67+75+56+63+78+82+76+71+75+76+76+64+73+77+89 \\
60+75+76+90+63+61+81+75+88+61+73+65+1+65+68+70+81 \\
77+60+73+90+67+65+70+53+70+79+59+67+56+54+55+58+44 \\
\hline \begin{array}{c}
10(10-1) \\
=\frac{\mathbf{6 1 0 9}}{\mathbf{9 0}}=\mathbf{6 8 . 2 1 1}
\end{array}
\end{gathered}
$$

Tabel .4 Data Matriks Dominan Concordance 


\begin{tabular}{|l|c|c|c|c|c|c|c|c|c|c|}
\hline NAMA & \multicolumn{1}{|c|}{ Data Milai Matriks Dominan Concordance } \\
\hline ASA TUAH ANAK NEGERI & - & 0 & 0 & 0 & 0 & 0 & 0 & 0 & 0 & 0 \\
\hline CAHAYA & 1 & - & 1 & 1 & 1 & 1 & 1 & 0 & 1 & 1 \\
\hline CAHAYA PLN & 1 & 0 & - & 1 & 0 & 0 & 0 & 0 & 0 & 0 \\
\hline FORMASI TUJUH & 1 & 0 & 1 & - & 1 & 0 & 1 & 0 & 1 & 1 \\
\hline HUTAMA KARYA & 1 & 0 & 1 & 1 & - & 0 & 1 & 0 & 0 & 1 \\
\hline KONDANG SEMARI & 1 & 1 & 1 & 1 & 1 & - & 1 & 0 & 1 & 1 \\
\hline KOPAKLI & 1 & 0 & 1 & 1 & 1 & 0 & - & 0 & 1 & 1 \\
\hline KOPANUSA & 1 & 0 & 1 & 0 & 1 & 0 & 0 & - & 1 & 1 \\
\hline KOPPAS 50 & 1 & 0 & 1 & 1 & 0 & 0 & 1 & 0 & - & 1 \\
\hline P 4 D & 1 & 0 & 0 & 0 & 0 & 0 & 0 & 0 & 0 & - \\
\hline
\end{tabular}

b. Menghitung Matriks Dominan Discordance

Nilai threshold (d) adalah

$d=\frac{\left\{d_{1,2}+d_{1.9}+d_{1,4}+\ldots \ldots \ldots+d_{10,9}\right\}}{10\{10-1\}}$

$$
=78.167 / 90=0.8653
$$

Tabel .5 Data Matriks Dominan Disordance

\begin{tabular}{|l|c|c|c|c|c|c|c|c|c|c|}
\hline NAMA & \multicolumn{7}{|c|}{ Data Nilai Matriks Dominan Disordance } \\
\hline ASA TUAH ANAK NEGERI & - & 1 & 0 & 1 & 0 & 1 & 0 & 1 & 1 & 0 \\
\hline CAHAYA & 0 & - & 0 & 0 & 0 & 1 & 0 & 0 & 0 & 0 \\
\hline CAHAYA PLN & 1 & 1 & - & 0 & 0 & 1 & 1 & 1 & 1 & 0 \\
\hline FORMASI TUJUH & 1 & 1 & 1 & - & 0 & 1 & 1 & 1 & 1 & 1 \\
\hline HUTAMA KARYA & 1 & 1 & 1 & 1 & - & 1 & 1 & 1 & 1 & 1 \\
\hline KONDANG SEMARI & 0 & 0 & 0 & 0 & 0 & - & 0 & 0 & 0 & 0 \\
\hline KOPAKLI & 1 & 1 & 1 & 1 & 1 & 1 & - & 1 & 1 & 0 \\
\hline KOPANUSA & 1 & 1 & 0 & 1 & 1 & 1 & 1 & - & 1 & 1 \\
\hline KOPPAS 50 & 0 & 1 & 0 & 1 & 1 & 1 & 1 & 1 & - & 0 \\
\hline P 4 D & 1 & 1 & 1 & 1 & 1 & 1 & 1 & 1 & 1 & - \\
\hline
\end{tabular}

\section{Menetukan Agregate Dominan Matriks}

Rumus umum untuk anggota matriks aggregate dominan adalah:

$$
E_{k l}=f_{k l} X g_{k l}
$$


Tabel .6 Data Perkalian Agregate Dominan Matriks

\begin{tabular}{|c|c|c|c|c|c|c|c|c|c|c|c|c|c|c|c|c|c|c|c|c|c|c|}
\hline \multicolumn{23}{|c|}{ Data Perkalian Agregate Dominan Matriks } \\
\hline $\begin{array}{l}\text { ASA TUAH } \\
\text { ANAK NEGERI }\end{array}$ & - & 0 & 0 & 0 & 0 & 0 & 0 & 0 & 0 & 0 & \multirow{10}{*}{$\mathbf{x}$} & $\begin{array}{l}\text { ASA TUAH } \\
\text { ANAK NEGERI }\end{array}$ & - & 1 & 0 & 1 & 0 & 1 & 0 & 1 & 1 & 0 \\
\hline CAHAYA & 1 & - & 1 & 1 & 1 & 1 & 1 & 0 & 1 & 1 & & CAHAYA & 0 & - & 0 & 0 & 0 & 1 & 0 & 0 & 0 & 0 \\
\hline CAHAYA PLN & 1 & 0 & - & 1 & 0 & 0 & 0 & 0 & 0 & 0 & & CAHAYA PLN & 1 & 1 & - & 0 & 0 & 1 & 1 & 1 & 1 & 0 \\
\hline $\begin{array}{l}\text { FORMASI } \\
\text { TUJUH }\end{array}$ & 1 & 0 & 1 & - & 1 & 0 & 1 & 0 & 1 & 1 & & $\begin{array}{l}\text { FORMASI } \\
\text { TUJUH }\end{array}$ & 1 & 1 & 1 & - & 0 & 1 & 1 & 1 & 1 & 1 \\
\hline HUTAMA KARYA & 1 & 0 & 1 & 1 & - & 0 & 1 & 0 & 0 & 1 & & HUTAMA KARYA & 1 & 1 & 1 & 1 & - & 1 & 1 & 1 & 1 & 1 \\
\hline $\begin{array}{l}\text { KONDANG } \\
\text { SEMARI }\end{array}$ & 1 & 1 & 1 & 1 & 1 & - & 1 & 0 & 1 & 1 & & $\begin{array}{l}\text { KONDANG } \\
\text { SEMARI }\end{array}$ & 0 & 0 & 0 & 0 & 0 & - & 0 & 0 & 0 & 0 \\
\hline KOPAKLI & 1 & 0 & 1 & 1 & 1 & 0 & - & 0 & 1 & 1 & & KOPAKLI & 1 & 1 & 1 & 1 & 1 & 1 & - & 1 & 1 & 0 \\
\hline KOPANUSA & 1 & 0 & 1 & 0 & 1 & 0 & 0 & - & 1 & 1 & & KOPANUSA & 1 & 1 & 0 & 1 & 1 & 1 & 1 & - & 1 & 1 \\
\hline KOPPAS 50 & 1 & 0 & 1 & 1 & 0 & 0 & 1 & 0 & - & 1 & & KOPPAS 50 & 0 & 1 & 0 & 1 & 1 & 1 & 1 & 1 & - & 0 \\
\hline P 4 D & 1 & 0 & 0 & 0 & 0 & 0 & 0 & 0 & 0 & - & & P 4 D & 1 & 1 & 1 & 1 & 1 & 1 & 1 & 1 & 1 & - \\
\hline$E_{71}=1 \mathrm{~B}$ & & & & & & & & & & & & & & & & & & & & & & \\
\hline
\end{tabular}

Tabel .7 Data Agregate Dominan Matriks

\begin{tabular}{|l|c|c|c|c|c|c|c|c|c|}
\hline NAMA & \multicolumn{7}{|c|}{ Data Nilai Agregate Dominan Matriks } \\
\hline ASA TUAH ANAK NEGERI & - & 0 & 0 & 0 & 0 & 0 & 0 & 0 & 0 \\
\hline CAHAYA & 0 & - & 0 & 0 & 0 & 1 & 0 & 0 & 0 \\
\hline CAHAYA PLN & 1 & 0 & - & 0 & 0 & 0 & 0 & 0 & 0 \\
\hline FORMASI TUJUH & 1 & 0 & 1 & - & 0 & 0 & 1 & 0 & 1 \\
\hline HUTAMA KARYA & 1 & 0 & 1 & 1 & - & 0 & 1 & 0 & 0 \\
\hline KONDANG SEMARI & 0 & 0 & 0 & 0 & 0 & - & 0 & 0 & 0 \\
\hline KOPAKLI & 1 & 0 & 1 & 1 & 1 & 0 & - & 0 & 1 \\
\hline KOPANUSA & 1 & 0 & 0 & 0 & 1 & 0 & 0 & - & 1 \\
\hline KOPPAS 50 & 0 & 0 & 0 & 1 & 0 & 0 & 1 & 0 & - \\
\hline P 4 D & 1 & 0 & 0 & 0 & 0 & 0 & 0 & 0 & 0 \\
\hline
\end{tabular}

J-SISKO TECH Vol. 3, No. 1, 2020 : 60-69 


\section{Eliminasi Alternatif yang Less Favourable}

Sehingga tabel perangkingan jika di tampilkan dalam tabel adalah sebagai berikut

Tabel .8 Data Perangkingan

\begin{tabular}{|c|c|c|c|c|c|c|c|c|c|c|c|c|}
\hline NAMA & & ta & Per & ans & $\sin$ & & & & & & Less Favourable & RANK \\
\hline FORMASI TUJUH & 1 & 0 & 1 & - & 0 & 0 & 1 & 0 & 1 & 1 & 5 & 1 \\
\hline HUTAMA KARYA & 1 & 0 & 1 & 1 & - & 0 & 1 & 0 & 0 & 1 & 5 & 2 \\
\hline KOPAKLI & 1 & 0 & 1 & 1 & 1 & 0 & - & 0 & 1 & 0 & 5 & 3 \\
\hline KOPANUSA & 1 & 0 & 0 & 0 & 1 & 0 & 0 & - & 1 & 1 & 4 & 4 \\
\hline KOPPAS 50 & 0 & 0 & 0 & 1 & 0 & 0 & 1 & 0 & - & 0 & 2 & 5 \\
\hline CAHAYA & 0 & - & 0 & 0 & 0 & 1 & 0 & 0 & 0 & 0 & 1 & 6 \\
\hline CAHAYA PLN & 1 & 0 & - & 0 & 0 & 0 & 0 & 0 & 0 & 0 & 1 & 7 \\
\hline P 4 D & 1 & 0 & 0 & 0 & 0 & 0 & 0 & 0 & 0 & - & 1 & 8 \\
\hline ASA TUAH ANAK NEGERI & - & 0 & 0 & 0 & 0 & 0 & 0 & 0 & 0 & 0 & 0 & 9 \\
\hline KONDANG SEMARI & 0 & 0 & 0 & 0 & 0 & - & 0 & 0 & 0 & 0 & 0 & 10 \\
\hline
\end{tabular}

\section{Kesimpulan}

Berdasarkan pembahasan mengenai Penerapan Metode ELECTRE (Elimination Et Choix Traduisant La Realite) didalam Sistem Pendukung Keputusan (SPK) untuk Penetuan Koperasi terbaik maka dapat disimpulkan: Sistem pendukung keputusan dengan metode ELECTRE dapat membantu dalam mengambil keputusan untuk menentukan Koperasi Terbaik pada Dinas Koperasi UKM Kota Pekanbaru serta dapat mengambil keputusan dengan tepat berdasarkan kriteria yang sudah ditentukan

\section{DAFTAR PUSTAKA}

Abner Adi Putra et al (2015). "Sistem Pendukung Keputusan Untuk Penerima Bantuan Pinjaman Samisake Dengan Metode Electre". urnal Rekursif, Vol. 3 No. 1,Hal. 1-11

Ardhi Bagus Primahudi et al (2016). "Sistem Pendukung Keputusan Untuk Pemilihan Karyawan Dengan Metode Simple Additive Weighting Di Pt. Herba Penawar Alwahida Indonesia". JIMP - Jurnal Informatika Merdeka Pasuruan Vol.2, No.1 Hal. 57-80

Fahmi Setiawan Et Al (2015)." Implementasi Metode Electre Pada Sistem Pendukung Keputusan Snmptn Jalur Undangan”. Kumpulan Jurnal IImu Komputer (Klik),Vol. 02, No.02, Hal. 88-101

Firdaus (2016). "Implementasi Simple Additive Weighting untuk Rekomendasi Pencari Kerja Terbaik Dalam Sistem Informasi Lowongan Kerja”. Jurnal Edik Informatik, Hal. 53-62

Mahammad et al(2016). "Aplikasi Pendukung keputusan Pemilihan Bakal Calon Anggota legislatif oleh Partai Politik di Indonesia dengan Metode AHP" Industrial Engineering Journal Vol.5 No.2, Hal. 4-10

Sri Rahayu Ningsih Et Al (2017)." Sistem Pendukung Keputusan Dengan Menggunakan Metode Electre Dalam Menentukan Penerima Program Indonesia Pintar (Pip) Melalui Kartu Indonesia Pintar (Kip)(Studi Kasus: Sd Swasta Al - Washliyah Moho Kabupaten Simalungun)". KOMIK (Konferensi Nasional Teknologi Informasi dan Komputer) Vol. I, No.1, Hal. 264-275

Wilis Kaswidjanti et al (2015). "Pengembangan Aplikasi Sistem Pendukung Keputusan Program Pengentasan Kemiskinan Di Kabupaten Bantul". Seminar Nasional Informatika, Hal. 326 332 